\title{
Cesarean Scar Defect (Isthmocele). When and how to treat?
}

\section{Isaac Melo Cerda MD}

Obstetric and Genecology in Charge of Colposcopy Department in the Oncologic Center in Hermosillo Sonora Mexico.

Corresponding Author: Isaac Melo Cerda MD, Obstetric and Genecology in Charge of Colposcopy Department in the Oncologic Center in Hermosillo Sonora Mexico

Received date: March 31, 2019; Accepted date: April 28, 2020; Published date: May 11, 2020

Citation: Isaac Melo. Cerda., (2020) CESAREAN SCAR DEFECT (ISTHMOCELE). WHEN AND HOW TO TREAT?. J Women Health Care Issues, 3(2); Doi:10.31579/ 2642-9756/027

Copyright: @ 2020 Isaac Melo Cerda, This is an open-access article distributed under the terms of the Creative Commons Attribution License, which permits unrestricted use, distribution, and reproduction in any medium, provided the original author and source are credited.

\begin{abstract}
Cesarean Scar Defect has been linked to Obstetric and Gynecological pathology, with the high number of patients undergoing $\mathrm{C}$-section end the frequency with which it is expected to have symptomatology, this prospective study try to find the frequency of Isthmocele, its symptomatology and with analysis of the literature propose factors to decide the best treatment. We confirmed the frequent of his presence, found that his symptomatology is based in spotting, dysmenorrhea and polymenorrhagia and found that the more symptomatic (RELEVANT) cases had cesarean scar defects bleeding producers and that the rest of symptomatic cases have cesarean scar defects bleeding collectors that often those not affect the daily life of the patient and don't require treatment. Finely we propose bases to take in count to decide treatment.
\end{abstract}

Keywords: Isthmocele, Cesarean Scar Defect, Isthmocele Treatment, Isthmocele Bleeding.

\section{Introduction}

In recent years the presence of abnormal placentation like Placental Previa, Placental Accreta, and Pregnancy in Caesarean Scars have increased. There is no doubt that the previous Caesarean section has importance in this genesis [1-3]. This has aroused interest in the detection of the Cesarean Scar Defect (CSD) also called Isthmocele. With the current use of diagnostic techniques such as Transvaginal Ultrasound and Hysteroscopy [3,4], a significant number of women with Caesarean history have been shown to present it. The patients with prior C-section have a CSD in between $20 \%$ and $86 \%$ [5]. In a paper published in 2014 [6]. I found that $62.4 \%$ of patients with Prior Caesarean Section had CSD, and $12 \%$ of them had a dehiscence of the scar.

Cesarean Scar Defects have been linked to abnormal uterine bleeding, dyspareunia, dysmenorrhea, and chronic pelvic pain [7]. Wang [8] found that $63.8 \%$ have abnormal uterine bleeding, $53.1 \%$ dysmenorrhea, $39.6 \%$ chronic pelvic pain and $18.3 \%$ dyspareunia, although Gubbini [9] links it to infertility.

If we take into account the very high number of patients undergoing Csection, the frequency in which these patients would have a symptomatology of Bleeding and Pain we would expect the symptomatology more frequently and more clearly. Also, the number of patients requiring surgery for this reason would be higher, and that we would have realized the existence and frequency of CSD long ago. These data led me to doubt that the symptoms of Pain and Bleeding are so frequent and important. We decided to do a prospective study to find the frequency of CSD, its symptomatology, and based on this symptomatology the characteristics of the patients and data in the literature analyze therapeutic behaviors.

\section{Material and Method}

Observational, Prospective and Comparative study, held from 1 January 2013 to 31 December 2015. Any patient who went to Colposcopy in the State Oncology Center of the State of Sonora in Mexico who had a history of Caesarean, was asked to authorize the practice a Hysteroscopy [6] and Endocervical Colposcopy with the Colposcopy. The Endocervical Colposcopy involves the use of Hysteroscopic to see the endocervical channel as a supplement to Colposcopy, using 3\% acetic acid to detect lesions within the channel [10].

Added to the Traditional Clinical History were: a) The Reasons and Conditions of the First Caesarean, b) Painful and Menstrual Symptoms with its characteristics, c) In case of symptomatology, if it produced so important symptomatology or feeling of disease to require surgery after knowing that the pathology in not a treatment for her held (Relevance), and d) Intentionally questioned the patient to see if there were any desires for a future pregnancy. Patients in Menopause, Diagnosed with Invasive Cancer or whose Hysteroscopy could not be practiced for technical reasons were excluded.

The total cases included were divided into two groups: Group A. Those with CSD and Group B. Those without CSD. A comparative statistical study was carried out in order to assess and compare the Symptomatology of Bleeding and Pain with its relationship to CSD. In a second part of the study patients with organic pathology (myomas, polyps, etc.) found in the clinical history on the examination or in the Hysteroscopy, and with factors 
that could modify menstruation such as the use of hormonals and intrauterine devices were also excluded. After this leak they were again divided into Group A and Group B and comparative statistical analysis was carried out.

Results.
Of 120 patients with a history of Caesarean 25 were excluded leaving 95 cases; $62(65.26 \%)$ in Group A (with CSD) and 33 (34.7\%) in Group B (without CSD) (figure 1 and Table 1and Table 2)

\section{Figure 1.}

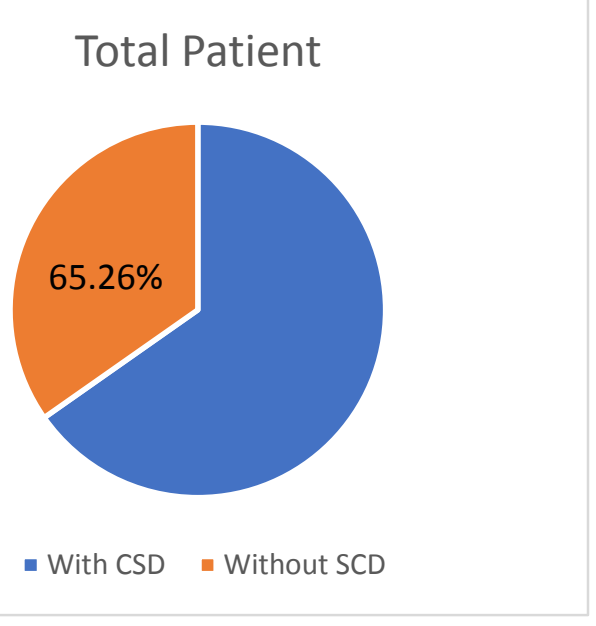

\section{Figure2.}

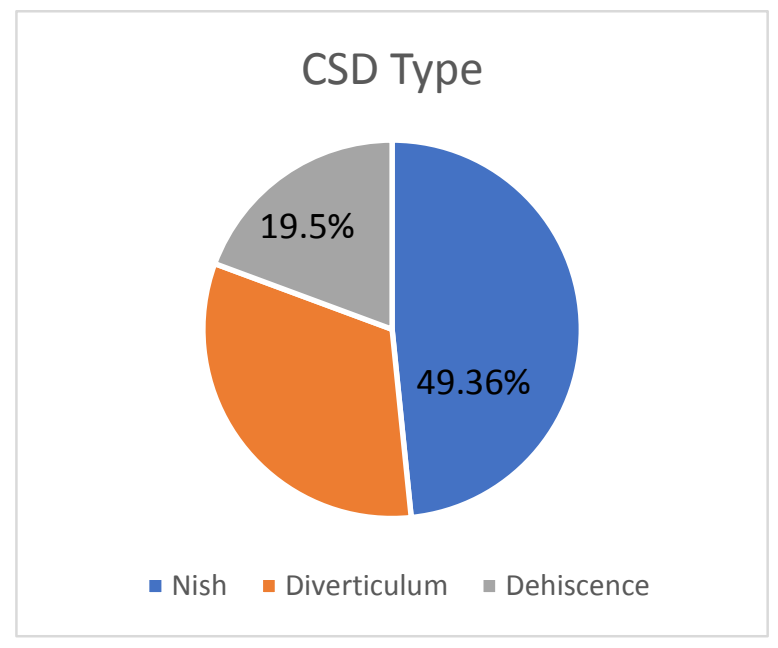

Of the 62 cases with CSD, 30 (49.36\%) were dome type, $20(32.25 \%)$ diverticulum type and $12(19.35 \%)$ had dehiscence (figure 2) (according to classification used in the previous study) [6].

General Data (Table 1) showed no significant statistical difference between the two groups. The Symptoms table (Table 2)shows that only the symptom of Spotting had a significant statistical difference, $64.51 \%$ of patients with CSD (p-02707 <0.05). After eliminating cases with factors that could change symptoms, 63 patients remained. Of these $45(71.42 \%)$ with CSD and 18 (28.57\%) were without as seen in Boxes 1 and 2.

After this filter differences statistically significance was found in patients with CSD in Spotting Polymenorrhagia and Dysmenorrhea Table 2, Spotting was present in $73.33 \%$ (p-0.0001<0.05), Polymenorrhagia in $31.11 \%$ (p-0.0050<0.05) and Dysmenorrhea in $31.11 \%$ (p-0.0056 <0.05). However, most importantly was that only 9 patients $20 \%$ had relevant symptoms refer to (Table 2).

\section{Figure 3}

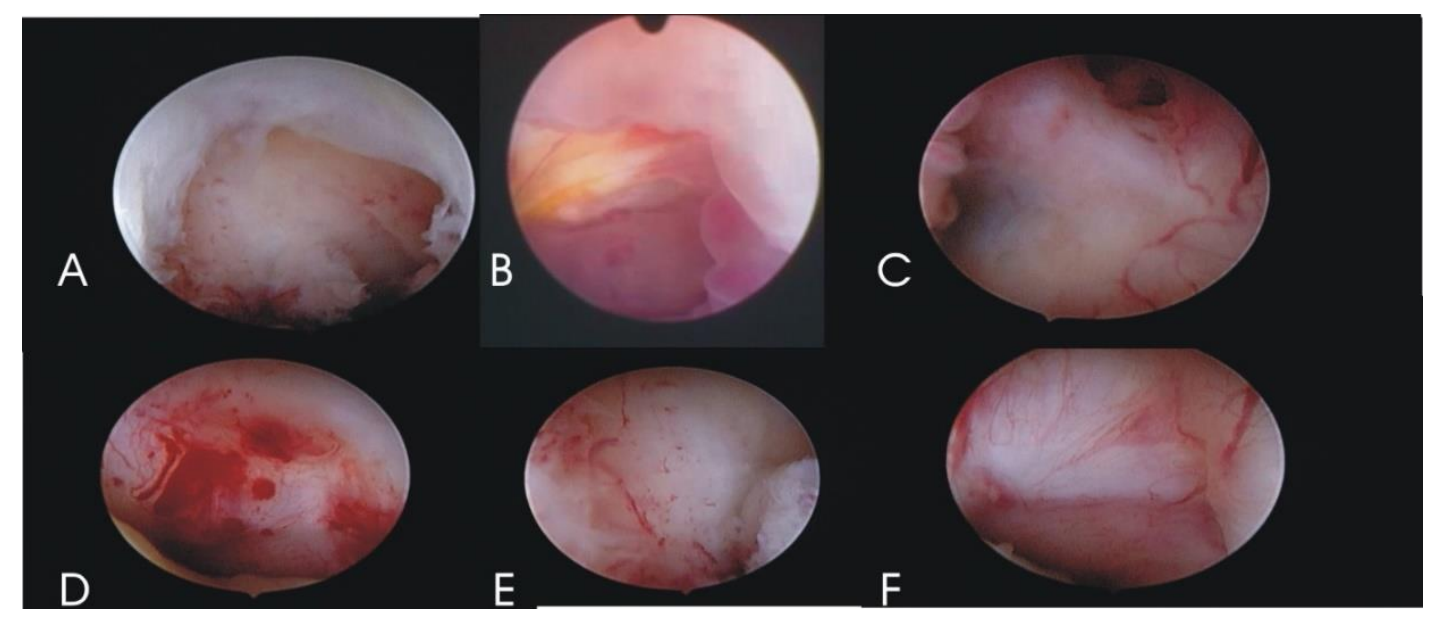

It is important to note that we found Cesarean Scar Defects with Endometrial or fibrous tissue covering the ceiling and/or side walls
(Figure 3 and F) of the Isthmocele and other CSD with granular-looking tissue, with increased vascularity and capillary and vascular bleeding 
(Figure 3 D). These findings strongly suggest that there are CSD "Bleeding Producers", which Morris [24] in 1995 had suspected its existence based on its histopathological findings but to date had not been demonstrated in image. These CSD "Bleeding Producers" (Figure 3 D and E), are related to the most symptomatic cases. While most are not Bleeding Producers, they are more likely "CSD or Isthmocele Collectors" which are those that act as a reservoir of menstrual bleeding and are less symptomatic. Traditionally this has been explanation for the symptom of bleeding or intermenstrual spotting $[3,12]$. CSD Producers are often symptomatic and have found two or more of the symptoms to be related to CSD, and in them we find the only two cases of secondary infertility.

\section{Discussion}

We confirmed the high presence of the Cesarean Scar Defect $65.26 \%$, similar to that found in 2014 [6], Total Dehiscence was presented at
$19.35 \%$, in 2014 were $12 \%$. This increase is justified by being a prospective study with a more careful and intentional exploration.

The symptomatology of pain and bleeding related to CSD is limited to Spotting, Polymenorrhagia and Dysmenorrhea. Hypogastric Pain, which is a very unspecific symptom in the gynecological patient, was most frequently found it in patients without CSD (44.44\%), although it showed no Significant Statistical Difference. These differences that doesn't match with Wang's studies [8] are surely due to the study being practiced with patients at a Colposcopy Clinic, a place that the patient does not go presenting symptomatology or gynecological upsets such as those presented to a Gynecology service and that Wang's study was descriptive and this is comparative.

\begin{tabular}{|c|c|c|c|c|c|c|c|c|c|c|}
\hline & $\begin{array}{l}\text { Patients } \\
\text { Group A }\end{array}$ & Group A & Grou & & & & & Group B & & \\
\hline & With Isthmoc & cele Withou & It Isthmocele & & After fil & Iter With Ist & hmocele & Without & & \\
\hline & Total $n=95$ & $\begin{array}{l}\mathrm{n}=6 \\
(65.26 \%)\end{array}$ & $n=33$ & & & $\begin{array}{c}\text { Total } \\
\mathrm{n}=63\end{array}$ & $\begin{array}{l}\mathrm{n}=45 \\
71.42 \%)\end{array}$ & $\begin{array}{l}\mathrm{n}=18 \\
(28.57 \%)\end{array}$ & & \\
\hline General Data & value & value & value & $\mathrm{p}$ & & value & value & Value & $\mathrm{p}$ & \\
\hline $\begin{array}{l}\text { Age, media } \\
\pm D S\end{array}$ & $33.81 \pm 8.54$ & $\begin{array}{l}33.43 \pm \\
8.84\end{array}$ & $33 \pm 8.71$ & $\mathrm{p}=0.8182$ & $>0.05$ & $\mid \begin{array}{l}34.63 \pm \\
7.96\end{array}$ & $\begin{array}{l}34.77 \pm \\
7.87\end{array}$ & $\begin{array}{l}34.27 \pm \\
8.40\end{array}$ & $\mathrm{p}=\underline{8289}$ & $>0.05$ \\
\hline $\begin{array}{l}\text { Pregnancy’s, } \\
\text { media } \pm \text { DS }\end{array}$ & $3.07 \pm 2.60$ & $2.95 \pm 1.4 \mathrm{C}$ & $92.84 \pm 1.48$ & $\mathrm{p}=0.7284$ & $>0.05$ & $3 \pm 1.60$ & $3.35 \pm 1.62$ & $3.44 \pm 1.58$ & $\begin{array}{l}\mathrm{p}=0.842 \\
\underline{2}\end{array}$ & $>0.05$ \\
\hline $\begin{array}{l}\text { First sexual } \\
\text { relationship }\end{array}$ & $17.88 \pm 3.62$ & $217.58 \pm 3.74$ & $4 \mid 17.63 \pm 4.16$ & $\mathrm{p}=\underline{0.9194}$ & $5^{>0.0}$ & $\begin{array}{l}18.41 \pm \\
3.92\end{array}$ & $18.48 \pm 3.51$ & $18.22 \pm 4.91$ & $\begin{array}{l}\mathrm{p}=0.834 \\
\underline{4}\end{array}$ & $>0.05$ \\
\hline \begin{tabular}{|l} 
Sexual \\
Partners
\end{tabular} & $3.07 \pm 2.60$ & $3.22 \pm 2.98$ & $\begin{array}{l}8.42 \pm 3.62\end{array}$ & $\mathrm{p}=\underline{0.7879}$ & $>0.05$ & $\begin{array}{l}3.15 \pm \\
2.92\end{array}$ & $2.73 \pm 1,67$ & $4.22 \pm 4.72$ & $\mathrm{p}=\underline{0.196}$ & $>0.05$ \\
\hline $\begin{array}{l}\text { Cesarean, } \pm \\
\text { DS }\end{array}$ & $1.75 \pm 0.83$ & $1.59 \pm 0.777$ & $\begin{array}{ll}7 & 1.66 \pm 0.85\end{array}$ & $\mathrm{p}=\underline{0.6962}$ & $>0.05$ & $\begin{array}{l}1.88 \pm \\
0.863\end{array}$ & $1.93 \pm 0.809$ & $1.77 \pm 1$ & $\begin{array}{l}\mathrm{p}=\underline{0.560} \\
\underline{1}\end{array}$ & $>0.05$ \\
\hline \begin{tabular}{|l|} 
Programed \\
No $\%$
\end{tabular} & $\begin{array}{c}44 \\
(46.31 \%)\end{array}$ & $22(35.48 \%)$ & $\begin{array}{l}22 \\
(66.66 \%)\end{array}$ & $\mathrm{p}=\underline{0.08511}$ & $>0.05$ & $\begin{array}{l}29 \\
(46.03 \%)\end{array}$ & $\begin{array}{l}17 \\
(37.77 \%)\end{array}$ & $12(66.66 \%)$ & $\mathrm{p}=0.037$ & $<0.05$ \\
\hline $\begin{array}{l}\text { Urgent No } \\
\%\end{array}$ & $\begin{array}{l}50 \\
(52.63 \%)\end{array}$ & $40(64.51 \%)$ & $\begin{array}{l}11 \\
(33.33 \%)\end{array}$ & $\mathrm{p}=0.7224$ & $>0.05$ & $\begin{array}{l}34 \\
(53.96 \%)\end{array}$ & $\begin{array}{c}28 \\
(62.22 \%)\end{array}$ & $\begin{array}{c}6 \\
(33.33 \%)\end{array}$ & $\begin{array}{l}\mathrm{p}=0.038 \\
5\end{array}$ & $<0.05$ \\
\hline $\begin{array}{l}\text { Wish of } \\
\text { Pregnancy }\end{array}$ & $11(11.57)$ & $6(9.67 \%)$ & $5(15.15 \%)$ & $\mathrm{p}=0.4763$ & $>0.05$ & $\begin{array}{l}7 \\
(11.11 \%)\end{array}$ & $4(8.88 \%)$ & $\begin{array}{c}3 \\
(16.66 \%)\end{array}$ & $p=0.1591$ & $1>0.05$ \\
\hline $\begin{array}{l}\text { Pills, DIU o } \\
\text { UP* }\end{array}$ & $32(33.68 \%)$ & $\begin{array}{l}17 \\
(27.41 \%)\end{array}$ & $\begin{array}{c}15 \\
(45.45 \%)\end{array}$ & $\mathrm{p}=0.1591$ & $>0.05$ & 0 & 0 & 0 & 0 & 0 \\
\hline$*$ Method of & $\begin{array}{l}\text { Family } \\
\text { plannin }\end{array}$ & $\begin{array}{l}* * \\
\mathrm{~Pa}\end{array}$ & $\begin{array}{c}\text { Uterine tholo } \\
\text { gy }\end{array}$ & & & & & & & \\
\hline
\end{tabular}

\section{Table-1}


Table-2

\begin{tabular}{|c|c|c|c|c|c|c|c|c|c|c|}
\hline \multirow[t]{3}{*}{ Patients } & \multicolumn{2}{|c|}{ Group 1} & \multicolumn{3}{|l|}{ Group 2} & \multicolumn{2}{|r|}{ Group 1} & Group 2 & & \\
\hline & \multicolumn{2}{|c|}{ With Isthmocele } & \multicolumn{3}{|l|}{ Without } & \multicolumn{2}{|c|}{ After Filter With Isthmocele } & \multicolumn{2}{|l|}{ Without } & \\
\hline & Total $n=95$ & $\begin{array}{l}n=62 \\
(65.26 \%)\end{array}$ & $n=33(34.73 \%)$ & $\mathrm{p}$ & & Total $n=63$ & $n=45(71.42 \%)$ & $\begin{array}{l}\mathrm{n}=18 \\
(28.57 \%)\end{array}$ & $\mathrm{p}$ & \\
\hline \multicolumn{11}{|l|}{ Symptoms of Pain } \\
\hline Pelvic Pain & $32(33.68 \%)$ & $\begin{array}{c}18 \\
(29.03 \%)\end{array}$ & $14(42.42 \%)$ & $\mathrm{p}=0.2941$ & $>0.05$ & $23(36.50 \%)$ & $15(33.33 \%)$ & $8(44.44 \%)$ & $\mathrm{p}=\underline{0.4301}$ & $>0.05$ \\
\hline Dyspareunia & $12(12.63 \%)$ & $\begin{array}{c}10 \\
(16.12 \%)\end{array}$ & $2(6.06 \%)$ & $\mathrm{p}=\underline{0.5248}$ & $>0.05$ & $8(12.69 \%)$ & $8(17.77 \%)$ & $0(0 \%)$ & $\mathrm{p}=\underline{0.1318}$ & $>0.05$ \\
\hline Dysmenorrhea & $15(15.78 \%)$ & $\begin{array}{c}15 \\
(24.19 \%)\end{array}$ & $0(0 \%)$ & $\mathrm{p}=\underline{0.0637}$ & $>0.05$ & $14(22.22 \%)$ & $\begin{array}{c}14 \\
(31.11 \%)\end{array}$ & $0(0 \%)$ & $\mathrm{p}=\underline{0.0056}$ & $<0.05$ \\
\hline \multicolumn{11}{|l|}{$\begin{array}{l}\text { Menstrual } \\
\text { Symptoms }\end{array}$} \\
\hline Hypermenorrhea & $5(5.26 \%)$ & $4(6.45 \%)$ & $1(3.03 \%)$ & $\mathrm{p}=0.6594$ & $>0.05$ & $2(3.17 \%)$ & $2(4.44 \%)$ & $0(0 \%)$ & $\mathrm{p}=\underline{0.8619}$ & $>0.05$ \\
\hline Polymenorrhagia & $23(24.21 \%)$ & $\begin{array}{l}19 \\
(30.64 \%)\end{array}$ & $4(12.12 \%)$ & $\mathrm{p}=\underline{0.4593}$ & $>0.05$ & $14(22.22 \%)$ & $14(31.11 \%)$ & $0(0 \%)$ & $\mathrm{p}=\underline{0.0050}$ & $<0.05$ \\
\hline Spotting & $44(46.31 \%)$ & $\begin{array}{l}40 \\
(64.51 \%)\end{array}$ & $4(12.12 \%)$ & $\mathrm{p}=0.02707$ & $<0.05$ & $34(53.96 \%)$ & $33(73.33 \%)$ & $\begin{array}{c}1 \\
(5.550 \%)\end{array}$ & $\mathrm{p}=0.0001$ & $\mid<0.05$ \\
\hline RELEVANT & $14(14.73 \%)$ & $\begin{array}{c}11 \\
(17.74 \%)\end{array}$ & $3(9.09 \%)$ & $P=0.2466$ & $<0.05$ & $10(15.87 \%)$ & $8(17.77 \%)$ & $0(0 \%)$ & $\mathrm{P}=0,2964$ & $>0.05$ \\
\hline
\end{tabular}

The most common symptom was Spotting at $73.33 \%$, a symptom that often does not affect patients' daily lives, as is shown by only $20 \%$ of them referring to it as a RELEVANT symptom.

We found that there are SCD "Bleeding Producers figure 3 "Isthmocele Producer"

https://youtu.be/oRYyXZnh0L4, with granulation epithelium, with capillaries and bleeding svessels, which occur in the relevant symptomatic cases, and are often accompanied by polymenorrhagia and dysmenorrhea. So far there is a belief that symptomatology is secondary to the accumulation of menstrual bleeding in the defect Nish [3,12,23], and is promoted as a surgical technique for its resolution the "Remodeling of the Isthmocele by Resectoscope". Resectoscope is a technique that is based on the elimination of the outer and internal rings of the defect [11]. This technique is needed to make fulguration or ablation of the ceiling and walls of the Nish as recommended by Ya-Ling Feng [13] to remove bleeding capillaries and vessels. In the case of a residual myometrium less than 2 [15] to $3 \mathrm{~mm}$ [17] this method cannot be used because of the risk of thermal damage to bladder. Osser [16] finds in $25 \%$ of patients with istmocel, a residual myometrium equal or less than $2.5 \mathrm{~mm}$.

Other surgical techniques to correct CSD should be known and taken into account, there are techniques of easy execution, vaginally [20,21] or laparoscopic $[3,14]$. Methods already described, which are simple to practice, and should be used in these cases. described, which are simple to practice, and should be used in these cases.

\section{Comment}

Faced with data from such a frequent anatomical alteration, that increases its importance and presence as a result of our therapeutic excesses (Unnecessary Caesarean). And, from the gynecological point of view, produces very frequent symptomatology $(73.33 \%)$ but of little relevance (20\%), while from the obstetric point of view it produces problems of infrequent Placentation (Placental Previa, Placental Accreta, Cervical Pregnancy and In Caesarean Scar Pregnancy), but of great Relevance (Obstetric Bleeding, Morbidity and Maternal Mortality). We must spread 
its existence and show that its appearance does not depend on the Technique or Surgical Skill of the Surgeon $[18,19]$, so that the decision of a C-section is more reasoned.

In the face of such common pathology therapeutic behavior should be established. Important aspects include:

a) Treat only the Symptomatic patient, and of these those who present Relevant Symptomatology.

b) Eliminate the Hysteroscopic Remodeling Technique without fulguration or ablation.

c) Do not do Hysteroscopic Remodeling in cases of myometrium less than $3 \mathrm{~mm}$.

d) Integrate Vaginal and Laparoscopic repair methods into treatments.

e) Perform vaginal or laparoscopic repair methods in patients who wish to get pregnant or in a study of sterility, and those with myometrium less than $3 \mathrm{~mm}$.

This Pathology, should be included in the I of Iatrogenic Causes of the Current Classification of Abnormal Uterine Bleeding FIGO PALMCOEINA and ACOG, and should be added and recognized as a Secondary Infertility Cervical Factor.

\section{Bibliography}

1. M. Morlando y col. Placenta Accreta: incidence and risk factors in an area with a particularly high rate of cesarean section. Acta Obstet Gynecol Scand. 2013, 92:457-460

2. M.F. Higgins y col. Real Increasing incidence of Hysterectomy for placenta accreta following previous cesarean section. Eur J Obstet Gynecol Reprod Biol. 2013, 171: 54-56.

3. Tower and Frishman. Cesarean scar defects: an underrecognized cause of abnormal uterine bleeding and other gynecologic complications. J Minim Invasive Gynecol. Sept 2013, 20, (5):562-572.

4. Talamonte VH y col. Hysteroscopic findings in patients with post-menstrual spotting with prior cesarean section. Eistein (Sao Pablo) 2012 Ene-Mar. 10(1):53-6

5. Roberge S, Boutin A. Systematic review of cesarean scar assessment in the nonpregnant state: imaging techniques and uterine scar defect. Am J Perinatol. 2012 Jun;29(6):465-471

6. I. Melo. Defecto en el Cierre de la Histerorrafia. Gin.Obt.Mex. 2014;82:530-34

7. T. Uppal y col. Sonographically detected caesarean section scar defects and menstrual irregularity. J Obstet Gynecol. Jul 2011, 31(5): 413-416.

8. Wang CB, Chiu WW. Cesarean scar defect: correlation between Cesarean section number, defect size, clinical symptoms and uterine position. Ultrasound Obstet Gynecol. 2009 Jul;34(1):8589.
9. Gubbini G y col. Surgical hysteroscopic treatment of cesareaninduced isthmocele in restoring fertility: a prospective study. J Minim Invasive Gynecol 2011; 18:234-237

10. I. Melo. ENDOCERVICOCOLPOSCOPIA: Método exploratorio complementario a la colposcopia. Mostrando su efectividad. Revista de Enfermedades del Tracto Genital Inferior. 2013, 7 (1). Pp. 5-11.

11. Shih CL. Hysteroscopic transcervical resection. A straightforward method corrects bleeding related to cesarean section scar . Am J Obstet Gynecol. 2011 Mar;204(3):278.e1278.e2

12. Bij de Vaate y col. Ultrasound evaluation of the Cesarean scar: relation between a niche and postmenstrual spotting. Ultrasound Obstet Gynecol 2011;37:91-399.

13. Feng et al. Hysteroscopic treatment of post cesarean scar defect. J Minim Invasive Gynecol 2012 Jul-Agos; 19(4):498-502.

14. Klemm y col. Laparoscopic and vaginal repair of uterine scar dehiscence following cesarean section as detected by ultrasound. J Perinat Med. 2005, 33(4):324-331.

15. Chang Y, Resectoscopic treatment combined with sonohysterographic evaluation of woman postmenstrual bleeding as a result of previous cesarean delivery scar defect. Am J Obstet Gynecol. 2009 Abril; 200(4): 370.e1-370.e4.

16. Osser OV, Cesarean section scar defects: agreement between transvaginal sonographic findings with and without saline contrast enhancement. Ultrasound Obstet Gynecol, 2010 Enero ; 35(1): 75-83.

17. Marotta y col. Laparoscopic repair of post-cesarean section uterine scar defects diagnosed in nonpregnant women. J Minim Invasive Gynecol, 2013 May-Jun; 20(3):387-391.

18. Roberge, S. Impact of single- vs double-layer closure on adverse outcomes and uterine scar defect: a systematic review and metanalysis. A J Obstet Gynecol 2014 Nov, 211(5):453-460

19. Bujold y col. The impact of single-layer closure on uterine ruptura. Obstetrics. 2002;186:1326-1330.

20. 20.- Khoshnow $Q$ y col. Transvaginal repair of caesarean scar dehiscence. Aust N Z J Obstet Gynecol,2010 Feb;50(1):94-95

21. Lou L. Vaginal repair of cesarean section scar diverticula. J Minim Invasive Gynecol. 2012 Jul-Agos;19(4):454-458.

22. Jastrow $\mathrm{N}$ y col. Impact of labor at prior cesarean on lower uterine segment thickness in subsequent pregnancy. Am J Obstet Gynecol. 2010 Jun;202(6): 563.e1-7

23. Bij de Vaate. Prevalence, potential risk for development and symptoms to the presence of uterine niches following cesarean section: symptomatic review. Ultrasound Obstet Gynecol 2014;43(4): 372-382.

24. Morris H. Surgical pathology of the lower uterine segment cesarean section scar: is the scar a source of clinical symptoms? Int J Gynecol Pathol 1995;14(1):16-20. 


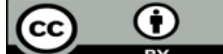

This work is licensed under Creative

Commons Attribution 4.0 License

To Submit Your Article Click Here: Submit Manuscript

DOI:10.31579/2642-9756/027
Ready to submit your research? Choose Auctores and benefit from:

* fast, convenient online submission

* rigorous peer review by experienced research in your field

* rapid publication on acceptance

* authors retain copyrights

* unique DOI for all articles

* immediate, unrestricted online access

At Auctores, research is always in progress.

Learn more www.auctoresonline.org/journals/women-health-care-andissues 